\title{
History and Development of Industrial Relations In Nigeria: Hybridity of Western Models Versus Military Interventionism Culture
}

\author{
Adebisi, Moses Adesola \\ Department of Sociology, University of Ilorin, \\ E-mail: masbisi@yahoo.com; mobile:+234(0) 8037147893.
}

Doi:10.5901/mjss.2013.v4n14p687

\begin{abstract}
The history and development of industrial relations in Nigeria is one that sprouted out of its colonial history which the British practiced and bequeathed to the post colonial independent Nigerian government led by the Sir Abubakar Tafawa Balewa, who became first Nigeria's Prime Minister on October 1, 1960, and the military culture of power seizure and interventionism. The colonialists established an industrial relations system that presented a structure of an admixture of the Anglo-Saxon model of tripartism (that is, a system of industrial relations which involved interaction among the key actors: employers, employees and government) and interventionism, which rely on the use of force to enforce compliance and prevention of industrial action. The paper attempts to establish a causal relationship between this hybridity of colonial rule and military intervention on the one hand, and the present day crisis-ridden industrial relations system of Nigeria. That is, it tries to show how the form of industrial relations system of Nigeria today reflects largely its historical antecedents. The paper concludes that the present day labourmanagement relations system of Nigeria can be properly appreciated if a cursory examination is conducted into its colonial history vis-à-vis its post-colonial military government and labour reforms that are designed mainly to establish the legal prescriptions and proscriptions for labour activities, employee-employer relations and labour relations with the government and its regulatory agencies.
\end{abstract}

Keywords: Industrial relations, western models, interventionism, hybridity, tripartism, actors, ideology.

\section{Introduction}

The history of industrial relations in Nigeria can be traced back to the colonial or even the pre-colonial era, when formal and semi-formal relationships where established with the British in particular and the Europeans in general. Such relationships led to the introduction of wage employment in a formal industrial setting. At the Berlin conference of 18841885, the British succeeded in formalizing its claims to the Nigeria Basin and the activities of some private entrepreneurs were brought under control of the Royal Niger Company headed by Sir Taubman George Goldie (Ubeku, 1993:37).

Meanwhile one administrative or political action of the British led to another, and eventually led to the amalgamation of the Northern and Southern protectorates in 1914 to form Nigeria. This new country was led by Lord Lugard, a British colonial administrator. As the country advanced both in age and development, the British colonial masters carried out a number of reforms in the labour sector, which created the legal frameworks for industrial relations in the country. Therefore by 1960, when Nigeria gained political independence from Britain which constituted industrial relations was largely derived or from the Anglo-Saxon model of industrial relations. These developments in the labour sector were no doubt without the activities of the nationalist and labour agitators at the time.

\section{Industrial Relations Defined}

The definitional conceptualization and scope of industrial relations is a subject of much controversy due mainly to the ideological or intellectual persuasions of those trying to define or conceptualize it. Therefore various schools of thought attempt to define the scope of industrial based on these factors. The main theoretical conceptions can be classified as follows:

(a). The Systems Models - John T. Dunlop

(b). The Oxford School - Allan Flanders 
(c). The Behavioural School - C. J Margerison

(d). The Marxist Approach - Richard Hyman.

Therefore, a closer examination of the fore-going theoretical conceptualizations will shed more light on the general character of industrial relations, in relation to the theoretical and practical application of impact of industrial relations within the Nigerian system.

\section{The Systems Model - John T. Dunlop}

The Systems Model is usually credited to the much respected American Professor of Labour Economics, John T Dunlop. According to Otobo (2000:16) Dunlop's seminar publication - Industrial Relations Systems (1956) drew great inspirations from the works of Professors Talcott Parsons and Neil J. Smelser, who were great advocates of the systems approach in their sociological analysis of the society. Hence, Dunlop (1958 cf: Otobo, 2000:18) describes the structure of industrial relations system in the following ways:

"An industrial relations system in its development is regarded as comprised of certain actors; certain contexts and ideology which binds the industrial relations system together and body of rules created to govern actors at the workplace and work community".

Basically therefore, Dunlop states that an industrial relations system must entails three main groups of actors:

(a). The workers and their organizations

(b). The employers and their associations

(c). Government agencies mainly concerned with work place and work community.

Other components of industrial relations are certain contexts i.e the technological, market, budgetary constraints, relations of power and the status of actors. Ideology and rules, which binds the industrial relations system together, are further components of the industrial relations system of Dunlop. Having stated all these structural components of an industrial relations system, Dunlop (1958) is of the view that "the task of any theory of industrial relations is to explain why particular rules are established and how and when they change in response to changes affecting the system" (Ubeku,1983:4).

\section{The Oxford School (Allan Flanders).}

Flanders (1965) in his conceptualization of industrial relations defines it as the study of the institutions of job regulation. His argument is based on the position that the only aspect of business enterprise that, directing concerns industrial relations is the employment, the relations between the enterprise and its employees and among the employees themselves (Ubeku 1983:5). According to this approach, in order to fully understand or identify these relationships among these afore mentioned elements in industrial relations, they must be placed in their legal setting. To Flanders (1965, cf: Ubeku 1985.5).

"They are all either expressed in or arise out of controls of employment (or service) which represents in common speech-jobs. The study of industrial relations may therefore be described as the study, of the institutions of job regulations".

Another major statement of the oxford school of Allan is one which states as represented by Ubeku (1983) that "the rules of any industrial relations system are either procedural or substantive". That is, the rules, which govern industries relations system, are determined by and large, by means of the rule-making process of collective bargaining. This has been described as a political institution involving a power relationship between employers and employees" (Ibid). The Oxford school also made a distinction between what it calls internal and external job regulations, and finally, the question of whether these rules can be changed automatically by labour (employees) and their organizations without the consent of an outside authority, i.e government or its agencies. 


\section{The Behavioural School (C.J. Margerison).}

The contribution of C.J. Margerison can be summarized briefly as follows:

(a). That industrial relations job content, constitute a complex field of study that requires its proper appreciation at both the behavioural and institutional levels.

(b). That conflict is an inherent feature of modern industrial society.

(c). That agreed rules are needed to resolve conflict or potential conflicts between the parties.

Based on the above, Margerison (1969) identifies two conceptual levels of industrial relation, of which conflicts could be generated.

Intra-plant level: Margerison believes that it is at this level that most of the conflicts are generated. At this level, situational factors like job content, work task and technology and interaction factors are said to generate three main types of conflicts-distributive, structural and human relations (Ubeku, 1983).

Outside the firm: this level deals with industrial relation problems that cannot be resolved at the intra-plant level. This is concerned mainly with the machineries for conflict resolution.

\section{The Marxist Approach (Richard Hyman)}

The publication of Industrial Relations: A Marxist introduction by Richard Hyman in 1975 constituted a major break with the way in which industrial relation had been portrayed or understood. Hyman (1975) states that the emphasis on the institutional school on rule-making rather than the sources or causes of conflicts was a disservice to our understanding of industrial relations. According to him, the state had always sided with the employers of labour in capitalist societies, so as to protect the interest of the bourgeoisie. In doing this, the workers interests are left unprotected. "The executive of the modern state is but a committee for managing the common affairs of the world bourgeoisie". (Hyman ,1975, cf; Ubeku 1983). To address or redress this injustice, Hyman says there is the need for the workers to fight for the democratization of the political institutions of the society. Having attacked the narrow definitional scope of maintenance of stability through rule making and enforcement, Hyman defines industrial relation "as the study of processes of control over work relations".

In summarizing the inputs from these various schools of thought on industrial relations, certain common grounds can be identified.

Any industrial relations system is made up of Actors - e.g. employers, employees and governmental agencies.

Contexts - i.e. technological context, market or budgetary constraints, and locus and distribution of power.

Rules - i.e. some agreed and established rules generated by interaction between the parties. In some cases rules are imposed on the parties by the government. Where they are imposed on the parties, i.e. employers and employees, they often constitute the source of strains and conflicts in industrial relations.

Ideology - Dunlop (1958) defines this ideology "as a set of ideas and beliefs held by the actors that help to bind or integrate the system together as an entity".

Meanwhile, these common grounds will appreciate the nature of industrial relations practice in Nigeria.

\section{Practice of Industrial Relations In Nigeria}

As stated earlier on in the introductory part of this paper, much of what becomes known as the industrial relations system of Nigeria derives from our colonial history. Nigeria was colonized by Great British, the first industrialized country, where industrial revolution began in the 1750s with the invention of the steam engine. The influence of this revolution in industry is beta examined under the rubric of the Anglo-Saxon model.

\section{The Influence of The Anglo-Saxon Model}

At the time British were industrializing, the philosophy of laissez-faire had been fully established as the intellectual substructure of all economic activities. Smith (1776) popularized this economic principle of laissez-faire with the publication of "The Wealth of Nations".

The basic principle of the Anglo-Saxon model of industrial relations is that workers and their employers are in the best position to deal with situational factors at work, especially the issue of conflicts arising from employment the issue of 
conflicts arising from employment matters. The state, therefore, should be a fair umpire in disputes settlement, having established the necessary legal frameworks upon which voluntary negotiation or collective bargaining is based.

Under the Anglo-Saxon model, the state does not intervene directly in any dispute settlement procedure involving the parties - labour and their employers. For instance, the right of labour to strike is recognised under this model of industrial relations.

Consequently, the British literally imposed its models and other institutional values on Nigeria. Hence, the AngloSaxon principles of voluntarism became the foundation of industrial relations practised in Nigeria.

Meanwhile, the Anglo-Saxon model of industrial relations was largely and eventually abandoned by the British for a number of reasons. First, the number of wage earners in Nigeria increased as increasing number of Nigerians had become paid employees. Second, the introduction of western education increased the level of awareness or consciousness as far as human right (right of labourers) is concerned. Third, the activities of early nationalist-war veterans, educated elites - raised the tempo of agitation for labour and democratic reforms. The British were neither prepared nor ready to accede to these demands. This forced them to abandon voluntarism for interventionism. The Aba Women Riots of 1929 and the coal miners' strike at Enugu in the 1940s, that were brutally suppressed, are classic historical flashpoints in the legendary quest by Nigerian workers for fair and humane conditions of work or service. The failure of the Anglo-Saxon model was highlighted by Kilby (1967:489-520)

\section{Independence and its Aftermath.}

In 1960, the British granted political independence to Nigeria and Dr. Nnamdi Azikiwe and Alhaji Abubakar Tafawa Balewa became president (in ceremonial capacity) and Prime, minister (head of government) and with executive powers respectively . Certain political crises in the west and middle belt of Nigeria were critical litmus test, which the new Balewa government handled poorly and wrongly. The Tiv riots and the AG crises of western Nigeria were resolved by military mean, which ushered in a new era of intervention in Nigeria. By 1966, Balewa's policy of inviting the military to deal with civil unrest backfired and two army coups occurred within a space of about six months (January and July).

\section{The Military Government And Industrial Relations Reforms In Nigeria}

The military coup of 1996 kept them in power till 1979 - a period of about thirteen years. During this period, the nation experienced a civil war the military suspended the constitution and ruled the decrees. However, the military authorities also introduced many radical reforms that changed the socio-economic and political atmospheres of the country. The Nigerian industrial landscape was greatly affected, as a number of labour laws, decrees and regulations were put in place by the military authorities.

The military era was therefore characterized by radical changes which amongst other things include grouping and regrouping of labour unions, promulgation of laws, especially those affecting labour, prescriptions and proscriptions of labour unions, arrest and detention of labour users and of course wage reforms, which led to increase in the minimum wage from the regime of General Yakubu Gowon in 1975 (Udoji Award) to general Abdulsalam Abubakar in 1999.

\section{Structure of Industrial Relations in Nigeria Today}

\section{Sources of Labour Laws in Nigeria:}

A number of labour laws and amendments were enacted or promulgated under military regimes at various times, especially since the first military coup of 1966. The following list represents a summary of the main laws promulgated by military decrees.

i. $\quad$ Trade Unions Act of 1973: The act in the main makes provision for the formation, registration and organization of trade unions, federation of trade unions and central labour organizations; it also specifies the category of those who could join trade unions or not or serve as officials.

ii. Labour Act of 1974: This act provides the general provisions in respect of wages, contracts and terms of employment; it also regulates procedure for recruitment and provides for some special categories of workers such as apprentices, women and young persons. However, the act does not apply to these category of workers:- the armed forces, police, administrative and executive, technical or professional workers. Domestic servants are also excluded from the labour act of 1974. 
iii. $\quad$ Trade Disputes Act of 1976: the Trade Disputes Act of 1976 establishes the time-table or time frame for the settlement of trade disputes between workers and their employers. The procedure for disputes settlement takes the following pattern: voluntary settlement-Mediation- Conciliation- Arbitration (at the National Industrial Court, I.A.P.) for determination. The Industrial Arbitration Panel, I.A.P.

iv. $\quad$ Trade Disputes (Amendment) Act of 1977: This act basically represents an amendment of Trade Disputes Act, TDA of 1976. Under this act, the minister of labour may take certain step where a trade dispute is apprehended by him. The act also establishes what constitutes offences and penalties for workers, trade unions and employers for any failure to comply with the Trade Disputes Act, TDA.

v. $\quad$ Trade Disputes (Essential Services) Act of 1976: The Trade Disputes(Essential Services) Act of 1976 empowers the President to proscribe any trade union whose members engage in essential services have taken part in acts calculated to cause industrial unrest;it also establishes the power of union members.

vi. $\quad$ Labour Amendment Act of 1978: This act amends the labour act of 1974 in other to make it obligatory for employers upon registration and recognition of a trade union to operate the 'check-off' system to cover all the employees qualified to be members of the trade union except those who contract out of the system in writing.

vii. $\quad$ Trade Unions (Amendment) Act of 1978: The trade unions amendment act of 1978 amends the trade unions act of 1973 as a result of the restructuring exercise carried out on the trade union by the federal military government; it also makes provision for the real organization of trade unions in Nigeria, and contains The list of registered and recognised trade unions.

viii. $\quad$ Trade Unions (Amendment) Act of 1979: This act shows which categories of officials belong to management cadres and could therefore not joined trade unions or hold office therein.

ix. $\quad$ Trade Unions (Miscellaneous) Decree of 1976:This decree amends the list of trade unions recognised and registered by the Registrar of trade unions into Part ' $A$ ' and Part ' $B$ '. The objective of this amendment is to distinguish between trade unions whose members are taken from the workers and those whose members are drawn from the senior staff and employers associations; the act also forbids deductions except on voluntary basis from wages and salaries and senior employees as contributors to the trade unions. Basically, the idea behind the amendment was to weaken the Senior Staff Associations.

x. Factories Decree of 1987: The decree, generally regarded by the various stakeholders as long overdue, repealed the old Factories Act by updating its provisions in line with contemporary conditions in the industry and the country in general. Hence, its application to a wider spectrum of workers and other professionals exposed to occupational hazards, and by making adequate provisions regarding the safety of workers by updating penalties provisions, had made it attuned with the current value of the naira, the country's official currency.

xi. Workmen's Compensation Decree of 1987: In the main, this decree re-enacts the Workmen's Compensation Act by adding new provisions in order to extend its coverage to benefit many more workers. It also removes the difficulties and delays inherent in the administration of the previous Act.

xii. $\quad$ Trade Disputes (Amendment) Decree of 1988: This decree amends the Trade Disputes Act of 1977 by reducing the periods provided in the Act for settlement of trade disputes referred to the courts to be determined within thirty days.

What constitutes industrial relations today can be seen in the procedures established by statutory regulations, which govern collective bargaining. The Nigerian industrial relations system is a hybrid of several systems - a combination of both voluntarism and state intervention - but to a great extent it is a product of Nigeria's history and development. Colonialism, military rule civil and inter-ethnic conflicts all combine in changing the industrial relations system from voluntarism to interventionism, which according to Ubeku (1983:186) is more production-oriented and also more integrative in its approach.

Therefore, the enactments as stated above provided the fundamental legal frameworks for collective bargaining within industry, and the actors have legalistic reference points or bases to indulge in negotiations.

The Nigerian system of industrial relations provides for collective bargaining at the national level. In Nigeria today, industrial conflicts can be resolved in two ways:

(a). Voluntary Procedure Process of internal machineries

(b). Statutory procedures (as contained in the Trade Disputes Act of 1976) i.e. external machineries. 
The principle of voluntarism has now been generally accepted in Nigeria as an established procedure for disputes settlement, and this is usually encouraged before any recourse to statutory procedures for the settlement of trade disputes. The main objective of the voluntaristic approach is to ensure that voluntary collective bargaining process between the parties lead to the resolution of any dispute between them. According to Diejomoah (1979), many firms in Nigeria lack proper grievance procedures which in his words:

"will cause poor bargaining (reflected in strikes, working to rule, lockouts, smissal, etc) and will lower worker morale, perhaps higher labour turnover rates, and malaise at the peremptory nature of decision" (cf: Ubeku, 1983)

The statutory procedures, for disputes settlement involve four stages, as directed by the labour minister sequel to the failure of voluntary procedures for disputes settlement. These stages are:

1. Conciliation

2. Arbitration

3. Inquiry

4. The National Industrial court

However, the highhandedness of the Nigerian government in respect of labour matter had made nonsense of these mechanisms or procedures for dispute settlement. More often than not, the Nigerian government fails to honour its own agreement with labour, thereby setting poor standards for employers in the poor sector. It has violated more agreement reached out of collective bargaining than any other institutions in Nigeria or the world over. A case in point is its failure or reluctance to honour a number of agreements with the Academic Staff Union of Universities, ASUU, and the Nigerian Labour Congress, NLC.

Consequently, the Nigerian industrial relations system today is replete with case of violation of negotiated agreements as a result of executive lawlessness as a result of the ubiquity of governmental power.

\section{Concluding Remarks}

This paper has attempted to present its own appreciation of the history and development of industrial relations in Nigeria. It posits that the nature or structure of industrial relations in Nigeria today owe largely to its colonial history, having been ruled by Britain. The basis of industrial relation in Nigeria, as identified by this paper lies in the Anglo-Saxon Model, although it also drew inspirations from other systems of industrial relations, especially the Germanic (i.e co-determination system), Soviet, Australian and the American systems, all of which have created a hybrid of the Nigerian system of industrial relations. The paper also highlighted the radical reforms of the military authorities and what now appears to be the permanent nature of interventionist policies of the Nigerian government in relation to industrial relations practice.

Finally, the paper examines the extant practice of industrial relations in Nigeria today and shows why it has failed as a result of governmental interference through highhanded policies and unpopular anti-labour law.

\section{Recommendations}

In an attempt to minimize industrial relations disputes in Nigeria, the following recommendations are made:

One, government should be faithful to its statutory role of an impartial arbiter who should not meddle unnecessarily in the disputes resolution procedures.

Two, parties to industrial relations disputes should embrace the principles of voluntarism rather than the usual recourse to statutory procedures which usually, makes government to intervene by imposing settlement on the parties. Usually, labour falls victims of such imposition by governments.

Three, government should immediately repeal some anti-labour laws that usually generate conflicts, e.g. Labour Amendments Act of 2004 which seeks to literally castrate labour in financial terms, by its attempt to make check-off dues paid by workers voluntary.

Four and finally parties to industrial relations disputes should endeavour to demonstrate more sincerity in their collective bargaining procedures. The usual attempt by government to repudiate agreements it reached through collective bargaining with labour at will should be discouraged for harmonious industrial relations to exist. If government 
would lead by example by demonstrating sincerity in its dealings with parties in industrial relations, it would have established exemplary precedence and leadership for durable and sustainable industrial relations to thrive in Nigeria. Unfortunately, the reverse is the case today where the econo-political system is bedeviled by monumental corrupt practices

\section{References}

Abiodun, M. O. (1978). Restructuring of Trade Unions in Nigeria: 1976-1978

Adeogun, A. A .(1969) "The Legal Framework of Industrial Relations in Nigeria" Nigeria Law Journal Vol 3 p.13-40.

Ananaba, W. (1969), The Trade Union Movement in Nigeria.Benin City. Ethiope Publishing Corporation.

Clegg, H.A.(1975). Pluralism in Industrial Relations", British Journal of Industrial Relations Vol 13, no 3, pp 309-16

Diejomoah, V.P (1979) "Industrial Relations in a Developing Context: The Case of Nigeria", Industrial Relations in Africa, ed. U.G Damachi et al. Macmillan.

Dunlop, J.T (1959), Industrial Relations Systems. Henry Holt.

Dunlop, J.T (1972). "Political systems and Industrial Relations," IILS Bulletine, No 9, Pg 99-116.

Flanders, A. (1965), Industrial Relations: what is wrong with the System? London: Faber and Faber.

Flanders, A. (1968). "collective bargaining: A theoretical analysis" British Journal Of Industrial Relations. Vol 6.pp 1-25.

Flanders, A. (1974), "The Tradition of Voluntarism. British journal of Industrial Relations vol. 12 No 3. P.365.

Hyman, R. (1975). Industrial Relations: A Marxist Introduction London: Macmillan.

Kilby, P. (1967). Industrial Relations and Wage Determination: Failure of the Anglo-Saxon Model, journal of Developing Areas, vol 1, pp489-520

Margerison, C. J. (1969). "What Do We Mean by Industrial Relations? A Behavioural Science Approach". British Journal of Industrial Relations Vol. 7. Pp273-86.

Miliband, R. (1975). The state in capitalist Society. Quartet.

Otobo, D. (2000).Industrial Relations: Theories and Controversies. Lagos. Malthouse Press Limited. Salama Press.

Ubeku, A. K. (1983). Industrial Relations in Developing Countries: The Case of Nigeria. London: Macmillan Press.

Yesufu,T.M (1962). An Introduction to Industrial Relations in Nigeria. Oxford: Oxford University Press. 
